Proceeding Paper

\title{
Citizen Energy Cooperatives in the Upper Rhine Region: Energy Transition and Social Transactions ${ }^{\dagger}$
}

\author{
Philippe Hamman
}

check for updates

Citation: Hamman, P. Citizen Energy Cooperatives in the Upper Rhine Region: Energy Transition and Social Transactions. Environ. Sci. Proc. 2021, 11, 12. https://doi.org/10.3390/ environsciproc2021011012

Academic Editor: Zia Lennard

Published: 25 November 2021

Publisher's Note: MDPI stays neutral with regard to jurisdictional claims in published maps and institutional affiliations.

Copyright: (C) 2021 by the author. Licensee MDPI, Basel, Switzerland. This article is an open access article distributed under the terms and conditions of the Creative Commons Attribution (CC BY) license (https:// creativecommons.org/licenses/by/ $4.0 /)$.
UMR 7363 SAGE/Institute for Urbanism and Regional Development, Faculty of Social Sciences, University of Strasbourg, 22 rue René Descartes, 67000 Strasbourg, France; phamman@unistra.fr † Presented at the Sustainable Places 2021, Rome, Italy, 28 September-1 October 2021.

Abstract: Based on a sociological fieldwork study (on-site observations, about a hundred interviews and five participatory workshops) in the three French, German and Swiss parts of the Upper Rhine Region (URR), this paper focuses on citizen energy cooperatives through a relational approach (between different actors, between production and consumption, etc.), as pointed out by the literature both in terms of socio-technical systems and of social transactions, including hybridisations when moving from enunciations to practical and territorialised experiences.

Keywords: energy cooperatives; renewable energy; transition; stakeholders; social transactions; property; alternative; local rootedness; networking; Upper Rhine Region

\section{Introduction}

From a sociological point of view, our main concern lies in studying how energy cooperatives in Europe produce social ties and collective projects, translating the social apprehension of ecological change, which may involve different approaches to energy transition [1].

This research focuses more precisely on local citizen energy cooperatives in the Upper Rhine Region (URR). Two aspects appear pivotal. On the one hand, energy issues are understood as a system, through a relational approach (between different actors, between production and consumption, etc.), as pointed out by the literature both in terms of sociotechnical systems and of social transactions. On the other hand, transformations are taking place continuously, including hybridisations when moving from enunciations to practical and territorialised experiences.

This contribution is based on a sociological fieldwork study of these initiatives in the three French, German and Swiss parts of the URR (on-site observations, about a hundred interviews and five participatory workshops). It examines successively: (i) the relations between commons, territories and energy cooperatives; (ii) the two major issues of ownership and of the possible alternatives to the market; (iii) the possibility of leading a "common action", when it proves to be in fact socially selective; and (iv) the dilemma of scale between local rootedness and extended networking.

\section{Thinking Together Territorial Commons and Energy Cooperatives}

There is no obvious link between common goods and local territories when one takes a "global" approach to the notion of common(s), on the assumption of its universal applicability to different international contexts (as biodiversity, for instance). Relations to the community thus appear as a central element. The meaning of energy commons is not limited to the management of a rarefied resource, but also embraces a process of territorial construction and the production of a sense of belonging. The copresident of the German photovoltaic cooperative BürgerEnergieGenossenschaft (BEG) Kehl thinks that carrying out such projects close to home helps people grasp what energy really is: "According to the statutes, only members from Kehl are accepted, and it has since extended 
to the neighbouring villages. [ . . . ] We want to keep it local for the citizens to become involved. [ . . . ] Many citizens think that energy flows from sockets and don't know how it is produced: they need to change their thinking" (RES-TMO Workshop, Strasbourg, 23 September 2019).

\section{Energy Cooperatives: Enabling Societal Alternatives?}

\subsection{The Question of Property}

Energy commons do not mean the end of property. First, any community must define the rules of access to specific resources and use patterns. The statutes of cooperatives often specify their field of action and mandate local participation, as illustrated by the German cooperative Fesa Energie Geno: "In our statutes, we need to have between 20 and 40\% participants directly from the area, especially for wind turbines. [ . . ] If I draw a circle of some kilometers around the installation, about $80 \%$ of the participants are within the circle" (cooperative manager, interview, 29 April 2019).

Moreover, as Elinor Ostrom argued [2], property translates into bundles of rights. Cooperative members are endowed with rights of access to the resource, rights of use, or are entitled to interests from the shares they hold. Other rights have to do with the specific governance arrangements: in cooperatives, the right to vote at general meetings is not tied to the amount of shares held, nor is decision-making: "The shareholders who wish to can be members of the management board, which is elected during the general meeting. I only have 300 euros of shares so far" (a member of the board, Centrales villageoises (CV) de Saverne, interview, 27 March 2020).

Finally, within the common property regime shareholders with quite different profiles can be found. Unsurprisingly, there are engineers, energy sector professionals or teachers, both active and retired, all endowed with technical, administrative, economic or educational capital, or with time to spare. However, all do not correspond to this type. There are also members experiencing downward social mobility and non-specialised employees, like this administrative secretary involved in CV de Saverne: "In the end I didn't pass the exams at Strasbourg Uni, so I sort of wasted time. [ . . . ] I worked, I did a lot of odd jobs and now I am working in an association, only part time though" (interview, 8 April 2020).

There can then be various reasons for joining. Energy advisors or energy transition officers working in local governments, for instance, can regard it as an extension of their professional activities. Other interviewees view the purchase of shares as a symbolic investment or a financial investment, perceived as such as well as valued for its "ethical" aspects. Others wish to act in a concrete way, in reaction against the radical or intellectual postures of some environmental activists.

For these reasons, energy cooperatives are not just a matter of grouping individuals together as of articulating together a set of anticipations, with the common good being the main focus of the members' involvement. The recurring reference made by the interviewees to the ecological metaphor of the hummingbird ("Do your part") is striking in this respect.

\subsection{What Alternatives to the Market Are There?}

The success of a local energy cooperative rests on the possibilities of articulating the economic, environmental and social cohesion aspects in a specific local environment. Local economic development is seen as an important aim: "When we talk of renewable energy, the idea is that [ ... ] it's better to finance a local installer, a local manufacturer, a panel assembler, which will be good for the local economy" (a member of the board of CV de Saverne, interview, 17 April 2019). However, there is no unified definition of what is actually understood as alternative, which can vary depending on a set of interrelated factors: the types of energy (fossil fuel/renewable sources), centralised-decentralised systems, the visibilisation of the energy circuit (not only "end of the pipe"), the linking together of production and consumption ("prosumers") or the hybrid functioning of production cooperatives selling their energy into the grid. 


\section{On Social Sustainability: Democratic Access or Club Goods?}

Membership of energy communities also raises the issue of social sustainability. The selective access to resources, goods or services, justified through reference to ecological transition, renewable energy and community projects, can maintain or even accentuate the dividing lines between those who can and cannot participate in an active manner: even though energy is presented as a common good, there can be a form of "monopolisation" by "local barons" [3]. This risk is mentioned in some interviews. For example, one of the heads of the German $B E G$ Endingen explained: "We also started with the limit of 20 shares for everybody because we didn't want some people to come with a lot of money, for example I give you 100,000 dollars but I want you to do the project the way I like it" (interview, 15 July 2019).

Interviewees often insisted on societal aims and on their indifference to profit-for instance: "It feels strange: legally speaking, it's a company, but it feels more like it's an association, you see. It's not the same spirit as a big capitalist company" (member of CV de Saverne, interview, 15 April 2020). These statements can be qualified in three ways. First, energy cooperatives do take economic viability into account, especially the feed-in tariffs. Second, the relation to "profitability" can be different depending on the structures and national contexts. On the German side, membership is openly presented as a financial investment. Third, there is a clear dividing line between project leaders and cooperative grass-roots members, who are not necessarily called upon to commit beyond the purchase of shares: "I didn't ask, and they didn't ask either. [ ... ] I think they're self-sufficient, they don't need anybody" (a shareholder in CV de Saverne, interview, 17 April 2020). The members of the board of BEG Endingen also have an expert profile: "We're very very glad to have an economic expert in our group, she is our specialist for account keeping. [ ... ] We have also a doctor of physics and we have a technical manager who takes care of the machinery. [ . . . ] He also was a former construction manager" (interview, 15 July 2020). Social capital expresses the immaterial part of energy commons and the link to a territory in which its value is bound to increase.

\section{The Dilemma of Scale: Local Rootedness vs. Extended Networking?}

Energy cooperatives experience a tension between planting deep local roots and promoting extended networks in a context of the globalisation of the commons, resulting in changes of scale: the "virtuous" ecological transition that energy communities intend to actualise includes the legitimisation, on a worldwide scale, of global commons. The initiatives under study show that their aim is to have a meaningful impact on a local scale while also ensuring their project is viable and can have real effectiveness in response to the global environmental issue, which provides an argument for the necessity of networking. The first deputy mayor of a village in Alsace, who also belongs to CV de Saverne, thus explained: "It's a bit like community work, but on another scale, here it's ultimately for the common good, and, we'll say, the good of the planet, even if it's just a drop of water for the moment" (interview, 14 April 2020). Similarly, one of the heads of BEG Endingen drew attention to distinct levels: "I think it's a good idea to let the group grow here in the city where people talk about direct projects for their city, but they can also be part of networks at different levels" (interview, 15 July 2019).

Local rootedness first grants legitimacy to energy cooperatives and project leaders. Some energy communities thus embody "resistance commons", which are identified by their strong embeddedness in the local area and rules adapted to the local context [4] (p. 120). They tend to pit themselves against the leading companies: "It's Total, EDF Énergies nouvelles, or whatever. It's the fight of David against Goliath. [ ... ] Their choices are always determined by questions of business, opportunities" (cooperator in Énergies partagées en Alsace, interview, 8 May 2020).

At the same time, a second defining aspect relates to practical coordination at different scales. An energy transition officer for a local government, who is also a member of $C V$ de Saverne, approached the topic in this way: "The advantage of CV projects [Centrales 
Villageoises being a French national network] is that the people who are going to become integrated into that type of projects, they're also going to have feedback from other groups, and so it will save them the trouble of having to start from scratch with the paperwork, etc." (interview, 27 March 2020). Whatever the national context, because of the technical questions that need to be mastered, cooperatives are inclined to organise as networks in order to be effective on a larger scale, as the president of Coopergy, a Swiss cooperative, explained: "Sharing expertise: We're not going to reinvent the wheel every time. Lobbying local governments and politicians concerning the price of energy: it helps do more than individually. Finally, it's necessary to acquire professional skills and to recruit: voluntary work has limits" (RES-TMO Workshop, 23 September 2019).

Studying the complex link between the commons and local territories thus reveals the double meaning given to community, as expressed in energy cooperatives: community as place, i.e., a set of social relationships rooted in a specific territory, and as network, extending beyond the specific limits of the territory and shaping a community of interests and/or values [5]. There is permanent tension between the two levels, which translates into the production of hybrid forms and territorial transactions [6] underlying the proclaimed ambition of achieving common, citizen and alternative action. The practical transactions conducted within the Swiss cooperative $A D E V$ in order to determine which institutional investors could be considered compatible with the project provide a good example of this: alongside individual shareholders, "there are different foundations who have a lot of money and who invest it in our cooperative. [ ... ] But there are no other energy suppliers, we don't want them", the head manager explained (interview, 2 April 2019). Common action cannot be taken independently from the reality of the social world; the risk is either to bolster the position of a preexisting economic "elite" or to produce new exclusive circles of "environmentalist" actors claiming sole legitimacy to act towards energy transition. Although it is defined as a common good, the process of transition is embedded within what could be considered as club-goods strategies, i.e., selective ones.

\section{Conclusions}

Social transactions over local citizen energy cooperatives and renewables in the URR embrace regulatory, economic, socio-technical as well as socio-political challenges:

- Making European/national regulatory frameworks match each other (urban planning documents, self-consumption regulations, feed-in tariffs, etc.);

- Incentives (cost and price of electricity, financial support) and economic issues of scale: larger projects are more profitable;

- "Go-between" actors are essential to deliver expert support for local governments as well as for networks of cooperatives, etc.;

- Agreeing on the principle of the energy transition ("better" or "less");

- Enabling all the actors to take part, not only the biggest ones;

- Considering the relation between general interest and local interest, i.e., solidarity between territories/interconnection for energy supply vs. autonomy;

- Encouraging individual action and local reappropriation of energy issues, but not forgetting the different capacity of people to act regarding social structures (landlord or tenant, etc.).

The importance of identifying these actors' games is the first major lesson of this study. This makes it possible to deepen current debates on the right to energy or on public/common goods, at the same time as showing how global environmental and climate issues appear to be concretely stratified by systems of actors that are both territorialised and networked, regarding the stakeholders involved in renewable energy transition processes. Second, this research shed light on the fine line separating "common goods" from "club goods" in the field of renewables. It thus insisted on the fact that the renewable energy transition cannot avoid raising the issue of just sustainability; this conclusion is a farreaching one in terms of energy projects and territories in the European context. 
Funding: This paper is published with the support of the European Union as part of the RES-TMO research project: Regional Concepts for an Integrated, Efficient and Sustainable Energy Supply and Storage in the Trinational Metropolitan Region Oberrhein (Upper Rhine). The RES-TMO project (Ref: 4726/6.3.) is co-funded by the EU programme Interreg V Upper Rhine through the European Regional Development Fund (EFRE/FEDER) for the period 1 February 2019-31 January 2022.

Informed Consent Statement: Informed consent was obtained from all interviewees in the study.

Data Availability Statement: See https:/ /www.res-tmo.com/en/.

Acknowledgments: The author expresses his thanks to Aude Dziebowski, Sophie Henck, Flandrine Lusson, Marie Mangold, Patricia Schneider and Mathilda Wingert for their support within the RES-TMO project, especially in conducting interviews.

Conflicts of Interest: The author declares no conflict of interest. The funders had no role in the design of the study; in the collection, analyses, or interpretation of data; in the writing of the manuscript, or in the decision to publish the results.

\section{References}

1. Hamman, P. Local Governance of Energy Transition: Sustainability, Transactions and Social Ties. A Case Study in North East France. Int. J. Sustain. Dev. World Ecol. 2019, 26, 1-10. [CrossRef]

2. Ostrom, E. Governing the Commons: The Evolution of Institutions for Collective Actions; Cambridge University Press: Cambridge, UK, 1990.

3. Nahrath, S.; Gerber, J.D.; Knoepfel, P.; Bréthaut, C. Gestion des ressources communes en Suisse. Nat. Sci. Soc. 2012, 20 , 39-51. [CrossRef]

4. Dardot, P.; Laval, C. Du public au commun. Revue MAUSS 2010, 35, 111-122. [CrossRef]

5. Walker, G. The Role for "Community" in Carbon Governance. Wiley Interdiscip. Rev. Clim. Chang. 2011, 2, 777-782. [CrossRef]

6. Hamman, P. (Ed.) Sustainability Governance and Hierarchy; Routledge: Abingdon, UK; New York, NY, USA, 2020. 